\title{
Effects of Feral Haw (Crataegus pinnatifida Bunge) Seed Extracts on the Antioxidant Activities
}

\author{
Yishan Duan, Min-A Kim, Han-Soo Kim*, Jong-Hwan Seong, Young-Guen Lee, Dong-Seob Kim and \\ Hun-Sik Chung
}

Department of Food Science \& Technology, Pusan National University, Miryang 627-706, Korea

Received January 9, 2014 /Revised January 27, 2014 / Accepted January 28, 2014

\begin{abstract}
Haw (Crataegus pinnatifida BUNGE) is a medicinal plant commonly used in Korea due to its beneficial health effects. This study was performed to investigate the antioxidative activity of bioactive components from haw seed. Freeze-dried seed was processed with various solvents such as $70 \%$ methanol, $70 \%$ ethanol, a mixture of chloroform and methanol (2:1, v / v), n-butanol and ethyl acetate (EA). $\mathrm{DPPH}$, reducing power, ferric reducing antioxidant power (FRAP), and ABTS radical scavenging activity decreased in this order: $70 \%$ methanol, $70 \%$ ethanol, EA, CM, $n$-butanol extracts. NO radical scavenging activity was high in the $n$-butanol extract $(36.73 \%$ in $0.8 \mathrm{mg} / \mathrm{ml}$ concentration) and low in the $70 \%$ ethanol extract $(24.96 \%$ in $0.8 \mathrm{mg} / \mathrm{ml}$ concentration). $\mathrm{OH}$ radical scavenging activity of $n$-butanol extract $(40.42 \%$ in $0.8 \mathrm{mg} / \mathrm{ml}$ concentration) was higher than the other extracts, but EA extract was the lowest $(13.39 \%)$ at the same concentration. The results show that each extract contained various antioxidative substances and it seemed that different influence at each antioxidative activity.
\end{abstract}

Key words : Antioxidative activity, Crataegus pinnatifida Bunge, hydroxyl radical, seed

\section{서 론}

산사(Crataegus pinnatifida BunGE)는 장미과(Rosaceae)의 열 매로 단맛과 신맛이 나고 우리나라 및 중국, 일본에 자생하고 있는 붉은색의 열매로 예로부터 항비만, 소화기질환 등에 이 용되어 왔으며, 중국에서는 높은 pectin 함량으로 인하여 젤 리나 잼으로 만들어 먹기도 한다[33, 40]. 산사에 함유되어 있 는 성분으로는 fructose, glucose, mannose와 같은 유리당, citric acid, acetic acid, succinic acid, malic acid 등의 유기산 과 quercetin, caffeic acid, catechin, salicylic acid, hyricetin, gentisic acid, ferulic acid, chlorogenic acid, narigin 등의 polyphenol 화합물이 있으며 $[25,28]$, 약리 성분으로는 (-)-epicatechin, isoquercitrin, pyrogallol, protocatechuic acid, hyperoside 등이 알려져 있다[18, 29]. 산사의 열수 추출물은 콜 레스테롤 생합성에 영향을 미치는 hydroxy-methyl-glutaryl $\mathrm{CoA}$ (HMG-CoA)에 대해 저해 활성을 나타낸다고 하며[24], D-galactose로 노화를 유발시킨 흰쥐에 산사 추출액을 섭취시 킨 결과, 적혈구의 SOD (superoxide dismutase)와 GSH-px (glutathione peroxidase)활성은 증가되었고, 혈장 내 총 지질

\footnotetext{
*Corresponding author

Tel : +82-55-350-535, Fax : +82-55-350-5359

E-mail : kimhs777@pusan.ac.kr

This is an Open-Access article distributed under the terms of the Creative Commons Attribution Non-Commercial License (http://creativecommons.org/licenses/by-nc/3.0) which permits unrestricted non-commercial use, distribution, and reproduction in any medium, provided the original work is properly cited.
}

농도의 감소 효과를 보여 항산화 및 지질과산화 억제 활성이 있다고 보고된 바 있다[20].

한편, 최근 건강에 대한 관심이 증가함에 따라 영양 및 기 능성을 갖춘 식품의 소비가 늘어나고 있으며, 특히 자연에 존 재하는 천연 생리활성물질(bioactive components)에 대한 관 심이 높아지고 있다[8]. 다양한 식물소재를 이용하여 항산화 를 비롯한 항암, 항균, 항돌연변이 등의 연구가 활발하게 이루 어지고 있는데 $[12,22]$, 식품 가공 중 부산물로 배출되는 씨를 이용하여 기능성 식품 소재로 활용하는 방안이 함께 연구되 고 있다[11]. 씨에 함유되어 있는 유용성분 및 생리활성에 관 한 연구로는 산수유 씨 methanol 추출물에서 분리된 화합물 의 최종당화산물(advanced glycation end products, AGEs) 생성 억제능[23], 홍화씨의 Staphylococcus aureus, Salmonella typhimurium균에 대한 항균 활성[39], 참외씨의 인체 유래 간 암(human liver cancer cell line, HepG2) 및 유방암(human breast cancer cell line, MCF-7) 세포주에 대한 항암 작용[17], 또한, 최근 reactive oxygen species (ROS)와 암, 노화 등 여러 질병과의 연관성이 제기되면서[36] 이러한 활성산소를 소거 하는 항산화 물질에 대한 중요성이 강조되고 있으며, 씨를 이 용한 항산화 활성에 관한 연구 $[35,38]$ 도 활발하게 이루어지 고 있으나, 산사씨에 대한 radical 소거 활성, 환원력 등의 항 산화 생리활성에 관한 연구는 거의 없는 실정이다.

따라서 본 연구에서는 생리활성 검정을 목적으로 야생산 사씨를 용매별로 추출하여 $\mathrm{DPPH}, \mathrm{FRAP}, \mathrm{ABTS}$ 등의 radical 소거 활성 및 환원력의 측정을 통하여 산사씨의 천연 항산화 제로서의 활용 가능성 및 biohealth 건강 기능성 식품 소재로 
서 다양한 식품 산업에 이용하고자 하였다.

\section{재료 및 방법}

\section{실험 재료}

실험에 사용된 시료는 강원도 정선군 남면 일대 야산에서 자생하고 있는 산사를 2011년 10월 하순 채취하여, 씨를 분리 한 후 진공동결건조(EYELA, FDU-2000, Rikakikai Co., Tokyo, Japan)시킨 다음, 분쇄기(DCM-5500, Dae-Chang, Seongnam, Korea)로 마쇄하여 $-80^{\circ} \mathrm{C}$ 의 deep freezer (SW-UF-400, SamWon Co., Busan, Korea)에 저장하며 본 실험에 사용하였다.

\section{시료 추출}

진공 동결된 산사씨 분말 $100 \mathrm{~g}$ 에 $70 \%$ methanol, $70 \%$ ethanol, chloroform:methanol (CM, 2:1, v / v), n-butanol, ethyl acetate (EA)의 5 가지 용매를 각각 10 배 가하여(1:10, w / v) 24시간씩 총 2회 추출하였고 여과지(filter paper, Advantec, No.1)를 이용하여 여과한 후, 각 추출물을 감압진 공농축기(EYELA, N-N series, Tokyo, Japan)를 사용하여 40 ${ }^{\circ} \mathrm{C}$ 에서 농축하였다. 농축된 추출물은 $-80^{\circ} \mathrm{C}$ (SW-UF- 400 , Sam-Won Co., Busan, Korea)에 저장하면서 시료로 사용하였 다. 산사씨 용매별 추출물의 수율은 $70 \%$ methanol에서 $10.38 \pm 0.30 \%$, $70 \%$ ethanol은 $10.23 \pm 0.17 \%$, CM $7.11 \pm 0.78 \%$, $n$-butanol $2.77 \pm 0.55 \%$ 및 EA $0.76 \pm 0.06 \%$ 를 얻어서 본 실험의 시료로 사용하였다.

\section{DPPH radical scavenging activity 측정}

$\mathrm{DPPH}$ radical 소거 활성은 Blois [2]의 방법에 준하여 시료 $1 \mathrm{ml}$ 와 $0.4 \mathrm{mM}$ DPPH $2 \mathrm{ml}$ 를 혼합하고 water bath에서 $37^{\circ} \mathrm{C}$, 30 분 동안 반응시켰다, 반응이 끝난 후, UV/VIS-spectrophotometer (Specord 200, Analytik-Jena, Jena, Germany)를 이용 하여 $518 \mathrm{~nm}$ 에서 흡광도를 측정하여 나타내었다.

DPPH radical scavenging activity $(\%)=\left(1-\frac{A b s_{\text {sample }}}{A b s_{\text {blank }}}\right) \times 100$

\section{Reducing power 측정}

산사씨 용매별 추출물의 reducing power는 각 시료 용액 $1 \mathrm{ml}$ 에 $0.2 \mathrm{M}$ phosphate buffer (pH 6.6) $2.5 \mathrm{ml}$ 및 $1 \%$ potassium ferricyanide $2.5 \mathrm{ml}$ 를 가하여 $50^{\circ} \mathrm{C}$ 에서 20 분간 반응시 켰다. 반응액을 5분간 냉각시킨 후, $10 \% \mathrm{TCA}$ (trichloroacetic acid) $2.5 \mathrm{ml}$ 를 첨가하여 $3,000 \mathrm{rpm}$ 에서 10 분간 원심분리 시 켰다. 상등액 $1 \mathrm{ml}$ 에 DW $3 \mathrm{ml}$ 및 $0.1 \%$ ferric chloride $1 \mathrm{ml}$ 를 가하고 10 분 동안 반응시킨 후 UV/VIS-spectrophotometer (Specord 200, Analytik-Jena)로 $700 \mathrm{~nm}$ 에서 흡광도를 측정하 였으며[14], 시료 용액 첨가군의 흡광도와 무첨가군의 흡광도 차이로 나타내었다.

\section{Ferric reducing antioxidant power (FRAP) 측정}

FRAP reagent는 $0.3 \mathrm{M}$ sodium acetate buffer ( $\mathrm{pH}$ 3.6) 및 $10 \mathrm{mM}$ 2,4,6-tripyridyl-S-triazine (TPTZ) solution, $20 \mathrm{mM}$ ferric chloride를 10:1:1 (v / v / v)의 비율로 혼합하여 $37^{\circ} \mathrm{C}$ 에서 10 분 동안 방치시켜 조제하였다. FRAP reagent $1.5 \mathrm{ml}$ 와 시료 $0.03 \mathrm{ml}$ 를 혼합하여 $37^{\circ} \mathrm{C}$ 에서 30 분간 방치시킨 후, UV/VIS- spectrophotometer (Specord 200, Analytik -Jena)로 $593 \mathrm{~nm}$ 에서 흡광도를 측정하였으며, 흡광도 자체를 항산화 력으로 나타내었다[13].

\section{ABTS radical scavenging activity 측정}

산사씨의 ABTS 소거 활성은 $\operatorname{Re}$ 등[34]의 방법에 준하여 측정하였다. 즉, $7 \mathrm{mM} \mathrm{ABTS}$ 와 $2.45 \mathrm{mM}$ potassium persulfate를 2:1(v / v)로 혼합하여 12 16시간 동안 방치한 후, 5 $\mathrm{mM}$ phosphate buffer (pH 7.4)를 가하여 $734 \mathrm{~nm}$ 에서 흡광도 가 $0.7 \pm 0.02$ 가 되도록 조절한 $\mathrm{ABTS}$ radical cation solution $2,800 \mu 1$ 와 시료 $200 \mu \mathrm{l}$ 를 섞어 6 분 후에 $734 \mathrm{~nm}$ 에서 흡광도를 측정하였으며 다음의 식에 의해 계산하였다.

ABTS radical scavenging activity $(\%)=\left(1-\frac{A b s_{\text {sample }}}{A b s_{\text {blank }}}\right) \times 100$

\section{NO radical scavenging activity 측정}

NO radical 소거 활성은 Yang 등[37]과 Badami 등[1]의 방 법을 변형하여 측정하였다. 시료 $0.5 \mathrm{ml}$ 에 $10 \mathrm{mM}$ sodium nitroprusside $0.5 \mathrm{ml}$ 를 가하여 $25^{\circ} \mathrm{C}$ 에서 150 분간 반응시켰다. 반응액에 $1 \%$ sulfanilamide $1 \mathrm{ml}$ 를 첨가하여 10 분간 방치한 후 $0.1 \%$ naphtylethylenediamide $1 \mathrm{ml}$ 를 가하여 30 분간 방치 하였다. 흡광도는 $540 \mathrm{~nm}$ 에서 측정하였다. 추출 용매별 산사 씨의 NO radical 소거활성은 다음의 식에 의해 계산하였다.

Nitric oxide scavenging activity $(\%)=\left(1-\frac{A b s_{\text {sample }}}{A b s_{\text {blank }}}\right) \times 100$

\section{Hydroxyl radical scavenging activity 측정}

추출 용매별 산사씨의 hydroxyl radical $(\mathrm{OH})$ 소거 활성 측정은 $10 \mathrm{mM} \mathrm{FeSO}_{4} 0.2 \mathrm{ml}, 10 \mathrm{mM} \mathrm{EDTA} 0.2 \mathrm{ml}, 10 \mathrm{mM}$ 2-deoxyribose $0.2 \mathrm{ml}$, 시료 $1.5 \mathrm{ml}, 0.1 \mathrm{M}$ phosphate buffer $2 \mathrm{ml}, 10 \mathrm{mM} \mathrm{H}_{2} \mathrm{O}_{2} 0.1 \mathrm{ml}$ 를 혼합한 후 water bath에서 $37^{\circ} \mathrm{C}$, 1 시간 동안 반응시켰다. 반응이 끝난 후, $2.8 \% \mathrm{TCA} 1 \mathrm{ml}$ 와 $1 \% \mathrm{TBA}$ (thiobarbituric acid) $0.5 \mathrm{ml}$ 를 첨가하고 $100^{\circ} \mathrm{C}$ 에서 10 분간 가열시킨 다음 급속히 냉각하여 $800 \mathrm{rpm}$ 에서 10 분간 원심분리 하였다. 흡광도는 $532 \mathrm{~nm}$ 에서 측정하였으며, 활성 정도는 다음 식을 이용하여 나타내었다[10].

$\mathrm{OH}$ radical scavenging activity $(\%)=\left(1-\frac{A b s_{\text {sample }}}{A b s_{\text {blank }}}\right) \times 100$

\section{통계처리}

분석 결과의 통계 처리는 실험군 당 평균치와 표준편차를 
계산하였고, 군간의 차이는 one-way analysis of variance (ANOVA, IBM SPSS statistics ver. 21) 분석 후 $p<0.05$ 수준에 서 Duncan's multiple range test에 의하여 각 실험군 간의 유의성을 검증하였다.

\section{결과 및 고찰}

\section{DPPH radical scavenging activity}

산사씨의 DPPH (2, 2-diphenyl-1-pikry-hydrazyl) radical

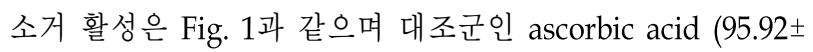
$0.00 \%, 95.98 \pm 0.00 \%$ 및 $95.98 \pm 0.00 \%)$ 를 제외한 모든 용매 추 출물에서 농도 의존적으로 증가하는 경향을 보였다. 용매별 산사씨 추출물은 $0.2 \mathrm{mg} / \mathrm{ml}, 0.5 \mathrm{mg} / \mathrm{ml}, 0.8 \mathrm{mg} / \mathrm{ml}$ 농도에 서 유의적인 차이를 보였으며 $70 \%$ methanol 추출물이 농도 별로 각각 $18.22 \pm 0.37 \%, 41.12 \pm 0.58 \%, 65.42 \pm 1.30 \%$ 의 가장 높 은 활성을 나타내었다. $70 \%$ ethanol 추출물이 $15.97 \pm 0.45 \%$, $37.20 \pm 0.49 \%, 60.25 \pm 1.28 \%$ 로 나타나 다음으로 높은 활성을 보 였으며, EA 추출물은 농도별로 $13.65 \pm 0.20 \%, 32.37 \pm 0.54 \%$, $54.02 \pm 0.62 \%$ 의 활성을 나타내었다. $\mathrm{CM}$ 추출물은 시료 농도 별로 각각 $11.01 \pm 0.18 \%, 24.66 \pm 0.14 \%, 39.88 \pm 0.73 \%$ 의 활성을 보였으며, $n$-butanol 추출물은 $9.37 \pm 0.37 \% 22.62 \pm 0.58 \%, 37.35$ $\pm 0.19 \%$ 로 용매 추출물 중 가장 낮은 활성을 보였다. $\mathrm{DPPH}$ 는 항산화 측정에 널리 이용되는 방법으로 항산화 물질이 $\mathrm{DPPH}$ 의 radical을 소거시켜 특유의 보라색을 탈색시키는데, 항산 화력이 강할수록 탈색되는 정도가 큰 것으로 알려져 있다 [26]. 7종의 한약재를 ethanol로 추출하여 DPPH 활성을 비교 한 결과, 금은화, 작약 및 포공영이 $60 \%$ 이상의 항산화력을 나타내었다고 하며[19], 산약 및 행인, 산사, 지실을 물과 ethanol로 추출하였을 때, 물 보다는 ethanol 추출물에서 활성

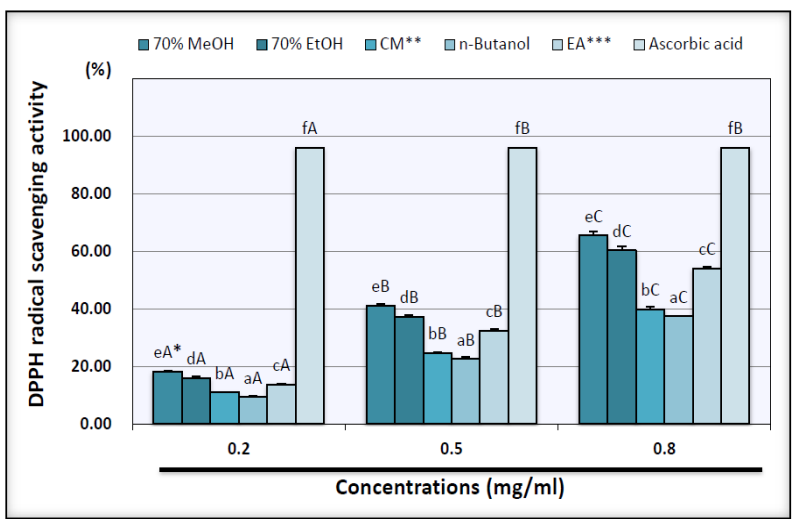

Fig. 1. DPPH radical scavenging activity of various solvent extracts of seed from haw (Crataegus pinnatifida BUNGE). "The data are presented as means \pm SD of 3 times. Means with different letters are significantly different at $p<0.05$ by Duncan's multiple range test. ${ }^{* *} \mathrm{CM}$; Chloroform: Methanol=2:1 ( / v). ${ }^{* * *}$ EA; Ethyl acetate.
이 더 높았고 시료 중에서는 산사의 전자공여능이 가장 높게 나타나 free radical 분해 효과가 우수하며, 추출 용매에 따라 항산화 효과의 차이가 생기기 때문에 추출 용매가 중요하다 고 하였다[32]. 따라서 본 실험 결과 추출 용매 중 $70 \%$ methanol 및 $70 \%$ ethanol 추출물이 가장 높은 DPPH radical 소거 활성을 보였다.

\section{Reducing power}

산사씨의 농도별 환원력은 Fig. 2와 같이, 시료 추출물의 농도가 높을수록 환원력은 증가하였으나, 대조군인 ascorbic acid $(0.615 \pm 0.023,1.340 \pm 0.021,2.303 \pm 0.058)$ 에 비하여 낮게 나타나 유의적인 차이를 보였다. $70 \%$ methanol 추출물은 농 도별로 각각 $0.046 \pm 0.002,0.103 \pm 0.002,0.170 \pm 0.005$ 의 환원력 을 나타내어 $0.2 \mathrm{mg} / \mathrm{ml}$ 농도를 제외한 모든 농도에서 유의적 으로 높은 환원력을 나타내었다. $70 \%$ ethanol은 $0.046 \pm 0.005$, $0.102 \pm 0.001,0.163 \pm 0.003$ 으로 $70 \%$ methanol 추출물 다음으로 높은 활성을 나타내었으나 $70 \%$ methanol 추출물과 유의적인 차이는 보이지 않았다. EA 추출물은 $0.040 \pm 0.001,0.088 \pm$ $0.003,0.150 \pm 0.002$ 의 활성을 나타내어 $70 \%$ methanol 및 $70 \%$ ethanol 추출물 다음으로 높은 활성을 나타내었으며, $\mathrm{CM}$ 추 출물이 $0.033 \pm 0.002,0.068 \pm 0.001,0.109 \pm 0.003, n$-butanol 추 출물이 $0.031 \pm 0.002,0.066 \pm 0.001,0.107 \pm 0.001$ 의 활성을 나타 내었고 서로간의 유의성 있는 차이는 없었다. Reducing pow$\mathrm{er}^{2} \mathrm{Fe}^{3+}$ 가 $\mathrm{Fe}^{2+}$ 로 환원되는 반응을 이용하여 측정하고 흡광 도 자체가 환원력을 나타내기 때문에 항산화력이 클수록 흡 광도 수치가 큰 것으로 알려져 있다[6]. 계피를 methanol로 추출하여 $1000 \mu \mathrm{g}$ 농도에서 환원력을 측정한 결과, 대조군인 $\mathrm{BHA}$ 의 약 $20 \%$ 에 상응하는 환원력을 나타내었으며[30], 가시 파래의 $n$-hexane, ethyl acetate 및 물 추출물의 환원력은 각각

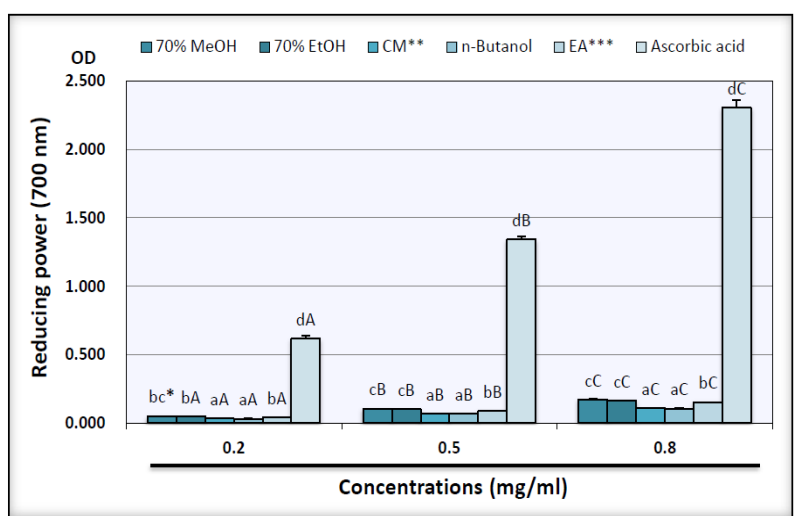

Fig. 2. Reducing power of various solvent extracts of seed from haw (Crataegus pinnatifida BunGE). "The data are presented as means \pm SD of 3 times. Means with different letters are significantly different at $p<0.05$ by Duncan's multiple range test. ${ }^{* *} \mathrm{CM}$; Chloroform:Methanol=2:1 (v / v). ${ }^{* * k}$ EA; Ethyl acetate. 
대조군인 ascorbic acid의 $58.9 \%, 98.3 \%, 74.9 \%$ 를 나타내어 ethyl acetate 추출물에서 가장 높은 환원력을 나타내었다고 보고된 바 있다[4]. 또한 산사 및 영지, 하수오 열수 추출물의 환원력은 산사에서 가장 높게 나타났으며 이는 시료 간의 성 분 조성 및 함량의 차이 때문이라고 하였다[27]. 따라서 본 실 험 결과 산사씨 $70 \%$ methanol 및 $70 \%$ ethanol 추출물에서 환원력이 높게 나타났으며, $n$-butanol 추출물에서 가장 낮은 것으로 확인되었다.

\section{Ferric reducing antioxidant power (FRAP)}

산사씨의 추출물에 따른 FRAP 활성은 Fig. 3과 같으며, 모 든 추출물에서 농도별로 유의적인 차이를 보였다. $70 \%$ meth$\mathrm{anol}$ 추출물은 시료 농도별로 각각 $0.086 \pm 0.002,0.179 \pm 0.003$, $0.288 \pm 0.005$ 를 나타내어 높은 활성을 보였으나, $0.2 \mathrm{mg} / \mathrm{ml}$ 농 도 이외의 모든 농도에서 $\mathrm{EA}$ 추출물과 유의성은 없었다. $\mathrm{EA}$ 추출물은 농도별로 각각 $0.079 \pm 0.001,0.175 \pm 0.003,0.287 \pm$ 0.010으로 나타났고, $70 \%$ ethanol 추출물은 시료 농도별로 $0.080 \pm 0.002,0.168 \pm 0.004,0.282 \pm 0.006$ 으로 나타나 모든 농도 에서 $\mathrm{EA}$ 및 $70 \%$ methanol 추출물간의 유의적인 차이는 보이 지 않았다. $\mathrm{CM}$ 추출물은 농도별로 각각 $0.060 \pm 0.002,0.120 \pm$ $0.002,0.189 \pm 0.008$ 의 활성으로 나타났다. $n$-butanol 추출물 또 한 $0.054 \pm 0.002,0.106 \pm 0.003,0.178 \pm 0.005$ 을 나타내어 $0.8 \mathrm{mg} /$ $\mathrm{ml}$ 농도 이외의 모든 농도에서 가장 낮은 활성을 나타내었다. 대조군인 BHA (butylated hydroxyanisole)는 농도별로 0.851 \pm 0.002 및 $1.808 \pm 0.009,2.054 \pm 0.003$ 의 활성을 나타내어 모든 농도와 추출물에서 유의적인 차이를 보였다. FRAP (ferric reducing antioxidant power)는 낮은 산도에서 $\mathrm{Fe}^{3+}$-TPTZ 복합 체가 $\mathrm{Fe}^{2+}-\mathrm{TPTZ}$ 복합체로 환원되는 원리를 이용하여 측정하 는 방법으로 총 항산화능을 확인할 수 있고, reducing power

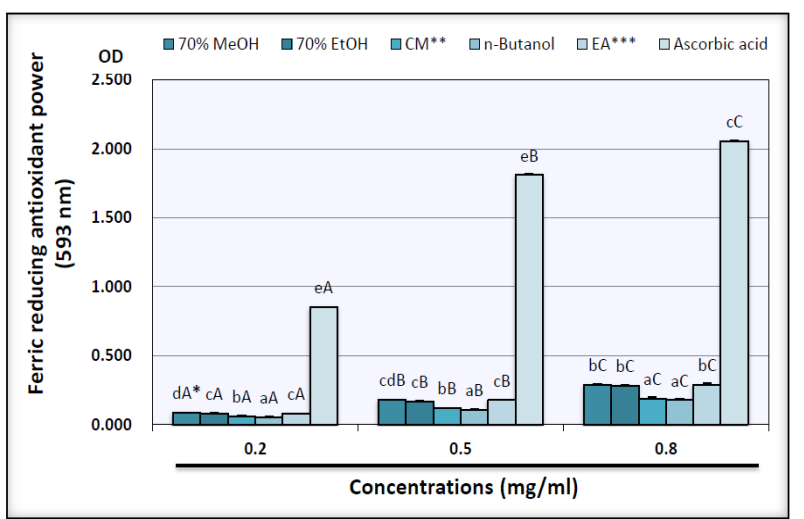

Fig. 3. Ferric reducing antioxidant power of various solvent extracts of seed from haw (Crataegus pinnatifida BUNGE). *The data are presented as means \pm SD of 3 times. Means with different letters are significantly different at $p<0.05$ by Duncan's multiple range test. ${ }^{* *} \mathrm{CM}$; Chloroform: Methanol=2:1 (v / v). ${ }^{* * *}$ EA; Ethyl acetate.
와 마찬가지로 흡광도 자체가 항산화력을 나타내므로 항산화 력이 클수록 흡광도 또한 높게 나타난다고 한다[3, 12]. 포도 씨와 머루씨 추출물의 FRAP 활성은 포도씨에서 더 높은 것 으로 나타났으며 DPPH radical 소거 활성의 결과와 일치한다 고 하였다[11]. 따라서 본 실험 결과에서도 FRAP는 DPPH 및 reducing power와 비슷한 경향을 보여, $70 \%$ methanol 및 $70 \%$ ethanol 추출물에서 가장 높게 나타났으며 $n$-butanol 추 출물에서 가장 낮은 것으로 확인되었다.

\section{ABTS radical scavenging activity}

산사씨의 추출 용매별 ABTS radical 소거 활성은 Fig. 4 와 같다. 대조군으로는 ascorbic acid 및 trolox를 사용 하였으며, 용매 추출물의 ABTS radical 소거 활성은 시료의 농도가 증가 할수록 높아지는 것으로 나타나 유의적인 차이를 보였다. 산 사씨의 $70 \%$ methanol 추출물은 시료 농도별로 $13.66 \pm 0.31 \%$, $33.99 \pm 0.37 \%, 59.21 \pm 1.45 \%$ 를 나타내어 용매 추출물 중 유의적 으로 가장 높은 활성을 나타내었고, $70 \%$ ethanol 추출물은 $12.44 \pm 0.15 \%, 30.75 \pm 0.37 \%, 52.94 \pm 1.14 \%$ 의 활성을 나타내어 $70 \%$ methanol 다음으로 유의적으로 높은 활성을 나타내었 다. EA 추출물은 농도별로 각각 $10.14 \pm 0.08 \%, 25.42 \pm 0.45 \%$, $43.34 \pm 1.62 \%$ 의 활성을 나타내어, $70 \%$ ethanol 다음으로 유의 적으로 높은 활성을 보였고, $\mathrm{CM}$ 추출물은 농도별로 $8.62 \pm$ $0.22 \%, 21.01 \pm 0.34 \%, 37.22 \pm 0.88 \%$ 의 활성으로 나타났으며, $n$-butanol 추출물은 $8.42 \pm 0.15 \%, 20.96 \pm 0.15 \%, 36.97 \pm 0.45 \%$ 를 나타내어 용매 추출물 중 가장 낮은 활성으로 확인되었으나 $\mathrm{CM}$ 과 $n$-butanol 추출물간에 유의적인 차이는 없었다. 대조 군인 ascorbic acid는 농도별로 $99.56 \pm 0.15 \%, 99.66 \pm 0.17 \%$, $99.76 \pm 0.08 \%$ 를 나타내었고, trolox는 농도별로 각각 $95.10 \pm$ $1.65 \%, 98.82 \pm 0.15 \%, 98.87 \pm 0.08 \%$ 의 활성을 보여 전 농도에서

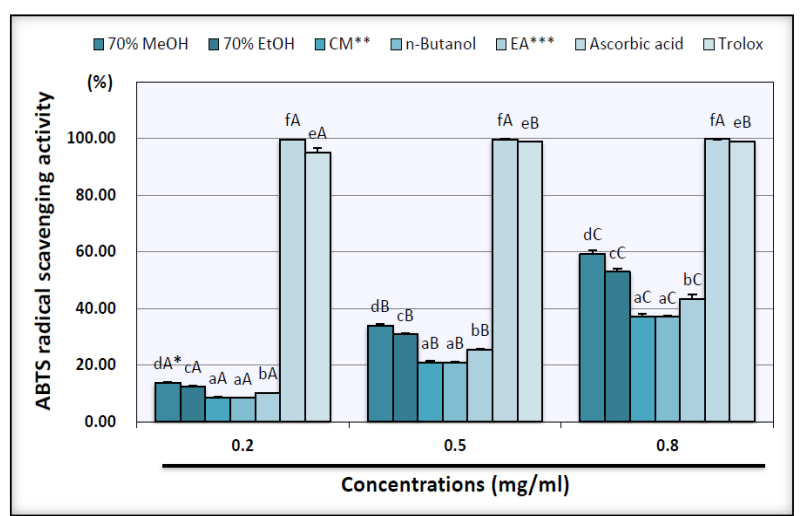

Fig. 4. ABTS radical scavenging activity of various solvent extracts of seed from haw (Crataegus pinnatifida BUNGE). "The data are presented as means \pm SD of 3 times. Means with different letters are significantly different at $p<0.05$ by Duncan's multiple range test. ${ }^{* *} \mathrm{CM}$; Chloroform: Methanol=2:1 (v / v). ${ }^{\star \star k}$ EA; Ethyl acetate. 
$95 \%$ 이상의 높은 활성을 나타내었다. ABTS [2, 2'-azino-bis (3-ethylbenzothiazoline-6-sulfonic acid) diammonium salt] 는 cation radical을 제거하며 지용성 및 수용성 물질을 확인 할 수 있고 trolox를 표준물질로 하여 비교할 수 있다고 한다 [15]. 톳 $n$-butanol 분획물의 ABTS 활성은 $65 \%$, BHA는 $80 \%$ 가 넘는 활성을 보였다는 보고도 있다[21]. 또한, 대추 과육 및 대추씨 추출물의 ABTS radical 소거 활성은 $10 \mu \mathrm{g} / \mathrm{ml}$ 농 도에서 과육보다 씨에서 더 높게 나타났으며, 대조군으로 사 용된 trolox, BHA 및 ascorbic acid 보다 낮은 것으로 나타났 고[38], $\mathrm{ABTS}$ radical 소거 활성은 $\mathrm{DPPH}$ 와 높은 상관관계를 보인다고 하였다[5]. 따라서 본 실험 결과에서도 ABTS radi$\mathrm{cal}$ 소거 활성은 $\mathrm{DPPH}$ 와 같은 경향을 보였다.

\section{NO radical scavenging activity}

산사씨 용매별 추출물의 NO radical 소거 활성은 Fig. 5 와 같으며, 씨에 있어서 $70 \%$ ethanol 추출물을 제외한 모든 추출 물에서 농도 의존적으로 유의적인 활성의 증가를 나타내었 다. $70 \%$ ethanol 추출물이 농도별로 각각 $6.61 \pm 2.87 \%, 17.41 \pm$ $4.17 \%, 24.96 \pm 3.55 \%$ 의 활성을 보여 추출 용매 중 가장 낮게 나타났다. $70 \%$ methanol 추출물이 농도별로 $8.17 \pm 1.52 \%$, $21.63 \pm 1.16 \%, 30.87 \pm 1.65 \%$ 로 나타나 $0.8 \mathrm{mg} / \mathrm{ml}$ 농도에서 $70 \%$ ethanol보다 유의적으로 높게 나타났다. $\mathrm{CM}$ 추출물은 농도별로 $17.09 \pm 2.12 \%, 22.28 \pm 0.89 \%, 29.79 \pm 0.38 \%$, EA 추출물 은 $17.44 \pm 0.94 \%, 23.40 \pm 1.63 \%, 33.07 \pm 1.35$ 로 나타나 $\mathrm{CM}$ 및 $\mathrm{EA}$ 추출물간에 유의적인 차이는 없었다. $n$-butanol 추출물은 농도별로 $25.72 \pm 0.77 \%, 28.38 \pm 0.58 \%, 36.73 \pm 0.84 \%$ 로 추출 용 매 중 유의적으로 높은 활성을 보였다. 대조군인 $\mathrm{BHA}$ 는 농도 별로 $43.68 \pm 4.76 \%, 94.34 \pm 0.09 \%, 95.30 \pm 0.30 \%$ 를 나타내어 유 의적인 차이로 증가하는 경향이었으며 용매별 추출물과도 유

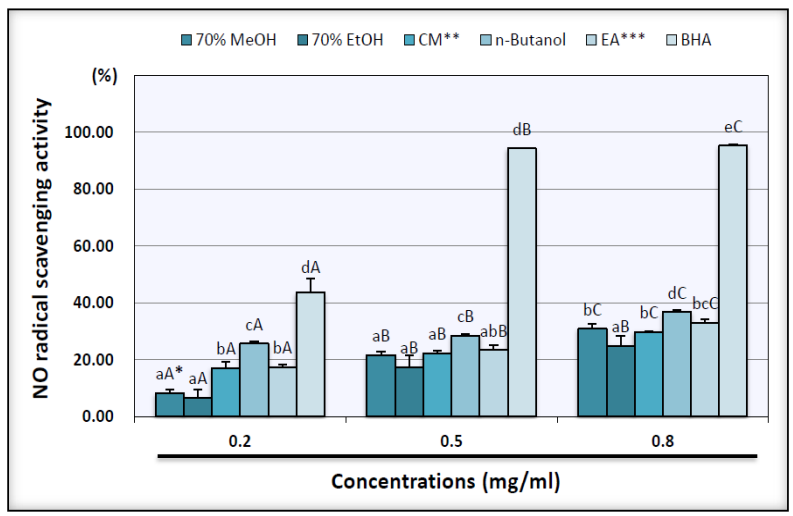

Fig. 5. NO radical scavenging activity of various solvent extracts of seed from haw (Crataegus pinnatifida BUNGE). "The data are presented as means \pm SD of 3 times. Means with different letters are significantly different at $p<0.05$ by Duncan's multiple range test. ${ }^{* *} \mathrm{CM}$; Chloroform:Methanol=2:1 (v / v). ${ }^{* * *}$ EA; Ethyl acetate.
의적인 차이를 나타내었다. NO는 free radical로 혈액 응고 등의 기능이 있지만 과량 존재하면 염증 인자 등으로 작용하 고 독성이 강한 산화제를 생성한다고 알려져 있다[37]. 생마 늘과 데친 마늘을 각각 물 및 ethanol로 추출하여 NO radical 소거 활성을 측정한 결과, 데친 마늘에 비하여 생마늘이 더 높은 소거 활성을 나타내었고 데친 마늘, 생마늘 모두 ethanol 추출물에서 더 높은 소거 활성을 보였다고 한다[16]. 또한, 산 사 및 인삼 혼합 추출물은 염증성 반응에 중요한 영향을 미치 는 NO 생성을, 대조군에 비하여 유의성 있게 억제 하여 염증 반응으로 인한 Alzheimer성 치매의 예방에 활용 될 수 있을 것이라는 보고도 있다[9]. 따라서 산사씨 추출물은 NO radi$\mathrm{cal}$ 소거 활성이 뛰어나 항산화 및 기능성 식품 소재로서 응용 될 수 있을 것으로 생각된다.

\section{Hydroxyl radical scavenging activity}

산사씨의 hydroxyl radical $\left(\mathrm{OH}^{-}\right)$소거 활성은 Fig. 6 과 같 이, 모든 추출물에서 농도 의존적으로 유의적인 활성 증가를 보였다. EA 추출물은 농도별로 $3.51 \pm 0.55 \%, 6.30 \pm 1.40 \%$, $13.39 \pm 2.05 \%$ 의 소거 활성을 보여 추출 용매 중 유의적으로 가 장 낮은 활성을 보였으며, $\mathrm{CM}$ 추출물 $(13.09 \pm 1.43 \%, 22.56 \pm$ $1.67 \%, 32.72 \pm 1.06 \%)$ 은 $70 \%$ ethanol 추출물 $(13.25 \pm 1.19 \%$, $25.07 \pm 1.08 \%, 35.31 \pm 2.46 \%$ )에 비하여 낮은 소거 활성을 나타 내었지만 유의적인 변화는 보이지 않았고, $70 \%$ methanol 추 출물 또한 농도별로 $14.10 \pm 1.42 \%, 26.04 \pm 0.99 \%, 35.44 \pm 1.00 \%$ 의 활성으로 $70 \%$ ethanol 추출물과 유의적인 차이를 나타내 지 않았다. $n$-butanol 추출물은 농도별로 $17.38 \pm 1.14 \%, 31.22 \pm$ $0.62 \%, 40.42 \pm 1.16 \%$ 로 추출 용매 중에 유의적으로 높은 소거 활성을 나타내었다. 대조군인 BHA는 농도별로 각각 $89.23 \pm$ $0.63 \%, 90.59 \pm 0.28 \%, 92.03 \pm 0.14 \%$ 를 나타내어 다른 용매 추출

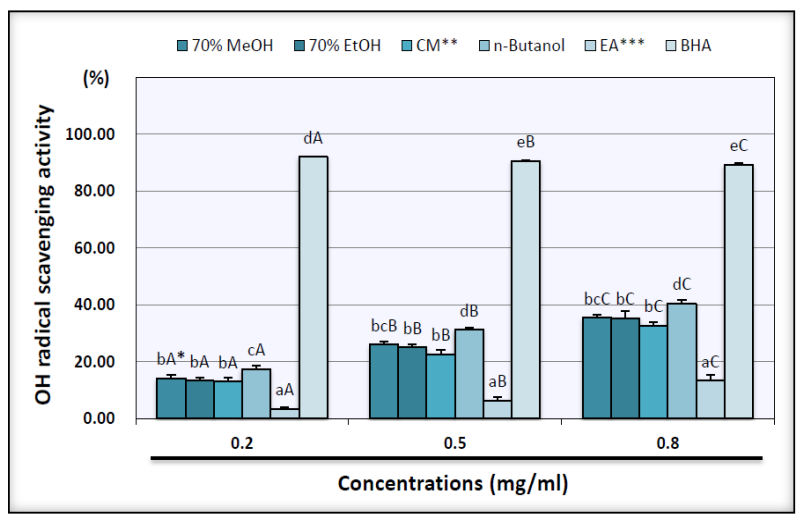

Fig. 6. $\mathrm{OH}^{-}$radical scavenging activity of various solvent extracts of seed from haw (Crataegus pinnatifida BUNGE). *The data are presented as means \pm SD of 3 times. Means with different letters are significantly different at $p<0.05$ by Duncan's multiple range test. ${ }^{* k} \mathrm{CM}$; Chloroform:Methanol=2:1 (v / v). ${ }^{* * *}$ EA; Ethyl acetate. 
물보다 유의적으로 높은 소거 활성을 보였다. Fenton's reaction에 의해 생성 되는 $\mathrm{OH}^{-}$radical은 지질, poly peptide 및 DNA 등과 반응하여 손상을 일으킨다고 알려져 있고, 항 암 및 항산화, low density lipoprotein (LDL) 산화 억제 등의 효과가 있는 isoflavonoid (genistein, genistin, biochanin A, daidzein)의 $\mathrm{OH}^{-}$radical 소거능을 측정한 결과 높은 활성을 나타내었다고 한다[7]. 추출 용매별 두릅 나무의 $\mathrm{OH}^{-}$radical 소거 활성은 acetone, chloroform, ethanol, methanol, water 순이었으며[10], methanol 및 $70 \%$ acetone으로 추출한 녹차 의 $\mathrm{OH}^{-}$radical 소거 활성은 각각 $44 \%, 35 \%$ 를 나타내어 methanol 추출물에서 더 높게 나타났다고 하였다[31]. 본 실 험 결과에서 산사씨의 $n$-butanol 및 $70 \%$ methanol 추출물이 높은 $\mathrm{OH}$ radical 소거 활성을 나타내어 산사씨 추출물은 천 연 항산화제로서 좋은 급원이 될 것으로 판단된다.

\section{References}

1. Badami, S., Gupta, M. K. and Suresh, B. 2003. Antioxidant activity of the ethanolic extract of Striga orobanchioides. $J$ Ethnopharmacol 85, 227-230.

2. Blois, M. S. 1958. Antioxidant determination by the use of a stable free radical. Nature 26, 1198-1200.

3. Cao, G. and Prior, P. L. 1998. Comparison of different analytical methods for assessing total antioxidant capacity of human serum. Clin Chem 44, 1309-1315.

4. Cho, M. L., Lee, H. S., Kang, I. J., Won, M. H. and You, S. G. 2011. Antioxidant properties of extract and fractions from Enteromorpha prolifera, a type of green seaweed. Food Chemistry 127, 999-1006.

5. Choi, Y. M., Kim, M. H., Shin, J. J., Park, J. M. and Lee, J. S. 2003. The antioxidant activities of the some commercial teas. J Korean Soc Food Sci Nutr 32, 723-727.

6. Chung, H. J. 2010. Antioxidative activities of different part extracts of Physalis alkekengi var. francheti (Winter Cherry). Korean J Food Preserv 17, 867-873.

7. Guo, Q., Rimbach, G., Moini, H., Weber, S. and Packer, L. 2002. ESR and cell culture studies on free radical-scavenging and antioxidant activities of isoflavonoids. Toxicology $179,171-180$.

8. Han, M. J. and Bae, E. A. 1996. Consumer opinions about the factor in food selection and functional food. Korean $J$ Dietary Culture 11, 299-304.

9. Han, S. H. and Kil, G. J. 2007. A study on the therapeutic effect of Alzheimer's disease of ginseng radix plus Crataegi fructus. Korean J Herbology 22, 35-40.

10. Hu, W., Jung, M. J., Heo, S. I. and Wang, M. H. 2008. Antioxidant and antidiabetic activities of Aralia elata seeds. J Appl Biol Chem 51, 111-116.

11. Hwang, I. W., Lee, H. R., Kim, S. K., Zheng, H. Z., Choi, J. U., Lee, S. H., Lee, S. H. and Chung, S. K. 2008. Proanthocyanidin content and antioxidant characteristics of grape seeds. Korean J Food Preserv 15, 859-863.

12. Jeon, Y. H., Won, J. H., Kwon, J. E. and Kim, M. R. 2011.
Antioxidant activity and cytotoxic effect of an ethanol extract from Seoritae. Korean J Food Cookery Sci 27, 1-10.

13. Jeong, C. H., Jang, C. W., Lee, K. Y., Kim, I. H. and Shim, K. H. 2012. Chemical components and antioxidant activities of black currant. Korean J Food Preserv 19, 263-270.

14. Jin, Y. W. and Fook, Y. C. 2009. Antioxidant properties of selected tropical wild edible mushrooms. J Food Compost Anal 22, 269-277.

15. Jung, E. H., Hwang, I. K. and Ha, T. Y. 2010. Properties and antioxidative activities of phenolic acid concentrates of rice bran. Korean J Food Sci Technol 42, 593-597.

16. Kang, M. J., Yoon, H. S. and Shin, J. H. 2012. Chemical properties and biological activity of garlic (Allium sativum L.) shoots. J Agric Life Sci 46, 129-139.

17. Kim, J. H., Suh, J. K. and Kang, Y. H. 2012. Anticancer effects of the extracts of oriental melon (Cucumis melo L. var makuwa Makind) seeds. Korean J Plant Res 25, 647-651.

18. Kim, J. S., Lee, G. D., Kwon, J. H. and Yoon, H. S. 1993. Identification of phenolic antioxidative components in Crataegus pinnatifica Bunge. J Korean Agric Chem Soc 36, 154157.

19. Kim, J. Y., Yi, Y. S. and Lim, Y. H. 2009. Biological and antifungal activity of herbal plant extracts against Candida species. Korean J Microbiol Biotechnol 37, 42-48.

20. Kim, K. H., Lee, S. S., Baek, J. W., Lee, S. J. and Kim, K. H. 2004. Effect of Crataegii fructus on antioxidant capacity in D-galactose induced aging rats. Korean $J$ Oriental Preventive Medical Soc 8, 65-80.

21. Kim, M. J., Lee, H. H., Seo, M. J., Kang, B. W., Park, J. U. and Jeong, Y. K. 2013. Antioxidation activities of organic solvent fractions obtained from seaweed, Hizikia fusiformis. J Life Sci 23, 361-367.

22. Ko, M. S. and Yang, J. B. 2011. Antioxidant and antimicrobial activities of Smilax china leaf extracts. Korean $J$ Food Preserv 18, 764-772.

23. Lee, G. Y., Jang, D. S., Lee, Y. M., Kim, Y. S. and Lim, J. S. 2008. Constituents of the seeds of Cornus officinalis with inhibitory activity on the formation of advanced glycation end products (AGEs). I Korean Soc Appl Biol Chem 51, 316-320.

24. Lee, H. J. and Choi, M. S. 1999. Measurement of inhibitory activities on 3-hydroxy-3-methyl glutaryl CoA reductase and acyl-CoA: cholesterol acyltransferase by various plant extracts in vitro. J Korean Soc Food Sci Nutr 28, 958-962.

25. Lee, J. J. and Lee, H. J. 2012. Comparisons of physicochemical composition of Korean and Chinese Crataegi fructrus. Korean J Food Preserv 19, 569-576.

26. Lee, J. M, Chang, P. S. and Lee, J. H. 2007. Comparison of oxidative stability for the thermally - oxidized vegetable oils using a DPPH method. Korean J Food Sci Technol 39, 133-137.

27. Lee, S. J., Shin, J. H., Kang, M. J., Yang, S. M., Ju, J. C. and Sung, N. J. 2009. Effect of garlic and medicinal plants composites on antioxidant activity and lipid levels of liver in hyper-cholesterolemic rats. J Life Sci 19, 1769-1776.

28. Lim, J. D., Yu, C. Y., Kim, M. J., Yun, S. J., Lee, S. J., Kim, 
N. Y. and Chung, I. M. 2004. Comparison of SOD activity and phenolic compound contents in various Korean medicinal plants. Korean J Med Crop Sci 12, 191-202.

29. Liu, P., Yang, B. and Kallio, H. 2010. Characterization of phenolic compounds in Chinese hawthorn (Crataegus pinnatifida Bge. var. major) fruit by high performance liquid chromatography lectrospray ionization mass spectrometry. Food Chem 121, 1188-1197.

30. Mathew, S. and Abraham, T. E. 2006. In vitro antioxidant activity and scavenging effects of Cinnamomum verum leaf extract assayed by different methodologies. Food Chem Toxicol 44, 198-206.

31. Manian, R., Anusuya, N., Siddhuraju, P. and Manian, S. 2008. The antioxidant activity and free radical scavenging potential of two different solvent extracts of Camellia sinensis (L.) O. Kuntz, Ficus bengalensis L. and Ficus racemosa L. Food Chemistry 107, 1000-1007.

32. Park, C. S., Yang, K. M. and Kim, M. L. 2006. Functional properties of medicinal plant extracts. Korean J Food Cookery Sci 23, 720-727.

33. Park, S. J., Shin, E. H. and Lee, J. H. 2012. Biological activities of solvent fractions from methanolic extract of Crataegi fructus. Korean J Food Nutr 25, 897-902.

34. Re, R., Pellegrini, N., Proteggente, A., Pannala, A., Yang, M. and Rice-Evans, C. 1999. Antioxidant activity applying an improved ABTS radical cation decolorization assay. Free
Radic Biol Med 26, 1231 -1237.

35. Ryu, I. H. and Kwon, T. O. 2012. The antioxidative effect and ingredients of oil extracted from Schizandra chinensis seed. Korean J Medicinal Crop Sci 20, 63-71.

36. Yang, R. L., Shi, Y. H., Hao, G., Li, W. and Le, G. W. 2008. Increasing oxidative stress with progressive hyperlipidemia in human: relation between malondialdehyde and atherogenic index. J Clin Biochem Nutr 43, 154-158.

37. Yang, S. A., Cho, J. H., Pyo, B. S., Kim, S. M. and Lee, K. I. 2012. Comparison of the physiological activities of extracts from different parts of Prunus sargentii. Korean $J$ Medicinal Crop Sci 20, 159-164

38. Yu, M. H., Im, H. G., Lee, H. J., Ji, Y. J. and Lee, I. S. 2006. Components and their antioxidative activities of methanol extracts from sarcocarp and seed of zizyphus jujuba var. inermis rehder. Korean J Food Sci Technol 38, 128-134.

39. Yu, S. Y., Lee, Y. J., Kang, S. N., Lee, S. K., Jang, J. Y., Lee, H. K., Lim, J. H. and Lee, O. H. 2013. Analysis of food components of Carthamus Tinctorius L. seed and its antimicrobial activity. Korean J Food Preserv 20, 227-233.

40. Zhu, R., Li, T., Dong, Y., Liu, Y., Li, S., Chen, G., Zhao, Z. and Jia, Y. 2013. Pectin pentasaccharide from hawthorn (Crataegus pinnatifida Bunge. Var. major) ameliorates disorders of cholesterol metabolism in high-fat diet fed mice. Food Res Int 54, 262-268.

\title{
초록 : 야생산사(Crataegus pinnatifida BUNGE)씨 생리활성물질의 산화억제 효과
}

\author{
Duan Yishan · 김민아 · 김한수 $*$ 성종환 · 이영근 · 김동섭 · 정헌식 \\ (부산대학교 식품공학과)
}

본 연구에서는 야생산사씨의 항산화 활성을 알아보고자 $70 \%$ methanol, $70 \%$ ethanol, chloroform:methanol $(\mathrm{CM}, 2: 1, \mathrm{v} / \mathrm{v}), n$-butanol, ethyl acetate (EA) 용매로 추출하여, 시료 농도 $0.2 \mathrm{mg} / \mathrm{ml}, 0.5 \mathrm{mg} / \mathrm{ml}, 0.8 \mathrm{mg} / \mathrm{ml}$ 에 서 측정 비교 하였다. DPPH, reducing power, FRAP 및 ABTS radical 소거활성은 70\% methanol, $70 \%$ ethanol, $\mathrm{EA}, \mathrm{CM}, n$-butanol 추출물 순으로 높게 측정되어 모두 같은 경향을 나타내었다. 특히, $\mathrm{DPPH}$ 에서 $70 \%$ methanol 추출물은 $18.22 \% ~ 65.42 \%, 70 \%$ ethanol 추출물은 $15.97 \%$ $60.25 \%$ 의 우수한 radical 소거 활성을 보였다. NO radi$\mathrm{cal}$ 소거 활성은 $n$-butanol, EA, CM, $70 \%$ methanol, $70 \%$ ethanol 추출물 순으로 나타났으며, $\mathrm{OH}^{-}$radical 소거 활성은 $n$-butanol, $70 \%$ methanol, $70 \%$ ethanol, $\mathrm{CM}, \mathrm{EA}$ 추출물 순으로 측정되었다. 모든 용매 추출물은 대조군으 로 사용한 표준물질에 비해서는 유의적으로 항산화 활성이 낮은 것으로 나타났다. 산사씨 용매 추출물 중 $70 \%$ methanol 및 $70 \%$ ethanol 추출물의 항산화 활성이 대부분 높은 경향이었다. 따라서 산사씨는 우수한 천연 항산화 제로 활용이 가능할 것으로 사료된다. 